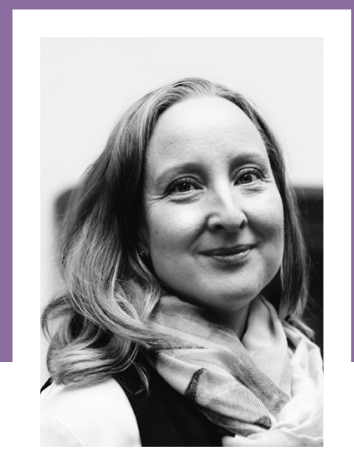

\title{
P̈̈̈KKIRJOITUS
}

\section{VAIKUTUSVALTAA VAIN SUURILLE?}

$\mathrm{P}$

ARHAILLAAN KEHITETÄÄN KANSALLISTA jatkuvan oppimisen toimintamallia. Tavoitteena on linjata käytänteitä ja kannusteita, joiden puitteissa aikuiset voivat kasvaa ja kehittyä elämänkulun eri vaiheissa. Miten aikuiskasvatuksen tutkijat osallistuvat tähän laajaan osaamisen kehittämistä ja aikuiskoulutusta koskevaan päätöksentekoon, vai osallistuvatko lainkaan? Uudistuksen valmistelu herättää kysymään, ketkä ovat vaikuttamassa aikuiskasvatuksen tulevaisuuteen.

Erityisesti taloustieteilijät näkyvät valtamediassa politiikan neuvonantajina, tutkijoina ja yrityskonsultteina. Saksalainen sosiologi Jens Maesse on tutkinut tapaa, joilla suuret kauppakorkeakoulut, erityisesti niiden tohtorikoulutus, osallistuvat talouden asiantuntijaelitismin vahvistamiseen.

VAIKUTUSVALTA EI OLE YKSILÖN OMINAISUUS, eikä se synny tyhjiössä. Yhteiskunnan suunnannäyttäjinä pidetyt huippuekonomistit tarvitsevat runsaasti taustajoukkoja. Siksi kaupallisella alalla tutkimusta, rahoitusta, akateemisia positioita ja palkkiota keskitetään strategisesti yhä suurempiin yksiköihin, jotka samalla velvoittavat tutkijoita yhä tiiviimpään yhteistyöhön, verkostoitumiseen ja yhteisjulkaisemiseen. Suuri mittakaava vahvistaa akateemista mainetta, joka puolestaan on avain yhteiskunnalliseen arvostukseen ja vaikuttamiseen.
Aikuiskasvatuksen tutkijoiden vaikutusvalta on perustunut toisenlaiseen toimintatapaan. Tutkijat ovat verkostoituneet vapaasti jakamiensa intressien ympärille ja vaikuttaneet järjestöissä, seuroissa ja muissa sivistysyhteisöissä. Tutkimusyhteistyö saa usein alkunsa kasvokkaisista tapaamisista. Yhdessä tekemistä on alalla paljonkin, mutta yhteiskunnallisen vaikuttamisen haasteina ovat yhteyksien sattumanvaraisuus ja tutkimuksen pirstaleisuus.

RUOTSALAISET AIKUISKASVATUKSEN PROFESSORIT Staffan Larsson ja Andreas Fejes ovat kartoittaneet aikuiskasvatuksen tutkimuskenttää sen perusteella, keiden tutkimuksia tiedeyhteisössä luetaan ja siteerataan. He puhuvat aikuiskasvatuksen "näkymättömästä kollegasta", sillä alalla on paljon tutkijoita, joiden tutkimus jää vähäiselle huomiolle ja joihin ei juurikaan viitata.

"Näkymätön kollega" tarkoittaa Larssonille ja Fejesille myös tutkijoiden keskinäisten viittauskäytäntöjen, sitaatioindeksien ja rankinglistojen vaikutusvaltaa. Tekstien väliset yhteydet ovat toimijoita, jotka ottavat mukaan elitistisiin piireihin vain tunnetuimmat ja tunnustetuimmat tutkijat. Aikuiskasvatus tutkimuskohteena ylittää tieteiden väliset rajat. Samalla sen tutkijat tulevat vahvistaneeksi omilla viittauskäytännöillään asiantuntijaeliitin olevan "toisaalla", kun he lähtökohtaisesti hakevat tutkimuksilleen vahvistusta oman tieteenalansa ulkopuolelta. 


\section{SUUNNANNÄYTTÄJÄT TARVITSEVAT}

TAUSTAJOUKKONSA.

TUTKIMUKSEN MÄÄRÄN JA PAINOARVON kasvattamisen tärkeydestä, tiedon kumuloitumisesta ja kollektiivisuudesta kirjoitettiin Aikuiskasvatuksessa painokkaasti viitisen vuotta sitten. Professori Kai Hakkarainen kollegoineen (4/2013) tarkasteli siirtymää yhteisjulkaisuihin perustuvaan kollektiiviseen malliin kasvatustieteiden tohtorikoulutuksessa. Kasvatustieteilijöiden yhteiskunnallista näkyvyyttä ja tutkimuksen vaikuttavuutta vahvistamaan tarvitaan nykyistä suunnitelmallisempaa yhdessä tekemistä ja tietoisuutta julkaisufoorumien merkityksestä tieteelliselle prosessille.

"KYK-kollektiivi” Helsingin yliopiston silloisesta käyttäytymistieteellisestä tiedekunnasta vastasi Hakkaraiselle ja kollegoille (2/2014), että yhteisöllisyyttä ei tulisi valjastaa akateemisen kapitalismin palvelukseen. Tutkijan työn ensisijaisena tavoitteena ei tulisi pitää akateemisen kilvoittelun ja yhteiskunnallisen elitismin vahvistamista.

Kuinka sitten ratkaistaan yhtälö pienen mittakaavan, näkymättömien aikuiskasvatuksen tutkijoiden ja kaventuvien yhteiskunnallisten vaikutusmahdollisuuksien välillä? Millainen rooli Aikuiskasvatuksen Tutkimusseuralla (ATS) ja Aikuiskasvatuksella on väljästi ja vapaasti organisoituneen tiedeyhteisön voimien yhdistäjänä? Potentiaalia niillä olisi toimia alan yhteiskunnallisena äänitorvena nykyistä vahvemmin.

Ajallinen ulottuvuus tuo keskusteluun uuden näkökulman. Moni merkittävä aikuiskasvatuksen vaikuttaja on saavuttanut suuruutensa - myös viittausten määrässä laskettuna - vasta vuosien kuluessa. Aikuiskasvatus palaa tutkimuksen perusteisiin marraskuussa Kasvatustieteen päivillä "Klassikon paluu” -teemaryhmässä, jossa pitkän linjan akateemisia ja yhteiskunnallisia vaikuttajia nostetaan esiin tuorein silmin. Samalla löydetään uutta inspiraatiota ja viedään tulevaisuuden aikuiskasvatusta eteenpäin.

Ulpukka Isopahkala-Bouret

\section{Lisää aiheesta:}

Fejes, A. \& Nylander, E. (toim.) (2019). Mapping out the Research Field of Adult Education and Learning. Lontoo: Springer.

Guttorm, H., Arvola-Orlander, A., Niemi, A.-M., Vaahtera, E., Mertanen, K., Tammi, T., MononenBatista Costa, S., Brunila, K., Kouhia, A., Paakkari, A., Kainulainen, V. \& Ikävalko, E. (2014). Akateeminen kapitalismi ja kollektiivisuuksien paradoksaalisuudet tohtorikoulutuksessa. Aikuiskasvatus 34(2), 121-128.

Hakkarainen, K., Hytönen, K., Makkonen, J. \& Lehtinen, E.(2013). Kollektiivista mallia voidaan soveltaa kasvatustieteiden tohtorikoulutuksessa. Aikuiskasvatus 33(4), 277-289.

Jatkuvan oppimisen kehittäminen (2019). Työryhmän väliraportti. Opetus- ja kulttuuriministeriön julkaisuja 2019:19. http://urn.fi/URN:ISBN:978-952-263-641-6. 